\title{
Use of Length of Radius for Estimation of Stature in Bengali Women
}

\author{
Dolan Champa Pal' ${ }^{1}$ Dhruba Mandal ${ }^{2}$, Asis Kumar Datta ${ }^{3}$
}

${ }^{1}$ Assistant Professor, Department of Anatomy, Calcutta National Medical College, Kolkata, West Bengal, India.

${ }^{2}$ Associate Professor, Department of Anatomy, Bankura Sammilani Medical College, Bankura, West Bengal, India.

${ }^{3}$ Professor \& Head, Department of Anatomy, KPC Medical College, Jadavpur, Kolkata, West Bengal, India.

\section{ABSTRACT}

\section{BACKGROUND}

Measurement of stature of an individual is of importance in forensic and medicolegal purpose. It can be done by direct measurement of the height of an individual or a cadaver. This is not always possible because the cadaver may be partially putrefied or destroyed, or it may so happen that only a body part is available. In this study, we tried to estimate the stature from the length of radius in living subjects.

\section{METHODS}

We took measurements (in centimeters) of height, length of left \& right radii of 510 Bengali healthy women between the age of 21 and 50 years. Scatter plot was drawn with regression lines to correlate height and left \& right radius length. We applied multiple linear regressions to develop a predictive equation for stature, based on age and radius length. Its validity was tested by drawing Bland-Altman plot of 30 additional randomly selected subjects, about their estimated height and actual height.

\section{RESULTS}

Height of the person showed strong correlation with length of left radius $(r=0.945$, $\mathrm{p}<0.001)$ and that of right radius $(\mathrm{r}=0.969, \mathrm{p}<0.001)$. The predictive equation for estimation of stature of Bengali women was $\mathrm{H}=39.2558+0.3671 \times \mathrm{LR}+4.4588 \times \mathrm{RR}$ $-0.003692 \times$ age \pm 1.6546 where $H=$ height of the women in $\mathrm{cm}, \mathrm{LR}=$ left radius length in $\mathrm{cm}, \mathrm{RR}=$ right radius length in $\mathrm{cm}$, age in years.

\section{CONCLUSIONS}

Stature of Bengali women can be estimated from the length of their left and right radius applying the above equation.

\section{KEY WORDS}

Stature, Length of Radius

\section{Corresponding Author:}

Dr. Dhruba Mandal,

Rabindrapalli, Burdwan-713101,

West Bengal, India.

E-mail: mandaldhruba@yahoo.com

DOI: $10.14260 / j e m d s / 2019 / 800$

Financial or Other Competing Interests: None.

How to Cite This Article: Pal DC, Mandal D, Datta AK. Use of length of radius for estimation of stature in Bengali women. J. Evolution Med. Dent. Sci. 2019;8(49):3698-3701, $10.14260 /$ jemds $/ 2019 / 800$

Submission 03-10-2019,

Peer Review 15-11-2019,

Acceptance 23-11-2019,

Published 09-12-2019. 


\section{BACKGROUND}

Stature is the natural height of a person in upright posture i.e. crown-heel length. This is determined mainly by genetic factors ${ }^{1}$ of the individual, and also by his health \& nutrition and diseases during infancy, childhood and adolescence ${ }^{2}$. Stature is important in characterisation of various genetic disorders, in sports, defence department, in the study of evolution and comparative anatomy of human and primates. Stature is very important in forensic and medico-legal purpose.

Stature can be calculated by anatomical or mathematical method. Anatomical method calculates total skeletal height (Sum of height of skeletal elements). For calculation of stature of a living subject by anatomical method, a correction factor is to be added (to compensate soft tissue).3,4,5 The main drawback of this method is that a complete skeleton is required. On the other hand, in mathematical method stature can be estimated from a body part e.g. length of the foot, breadth of the foot, length of superior or inferior extremity, length of different bones especially the long bones. ${ }^{6,7,8,9}$ Even the length of a single bone may predict the stature ${ }^{10}$. Stature varies with ethnicity, age, sex and heredity. According to Telkka, there should be a separate formula for estimation of stature for each racial group.

Most of the research work regarding estimation of stature is done on cadavers. Several fallacies are there in this regard; because most of the cadavers are aged, they might have suffered from chronic illness, or they may have abnormal posture and it is difficult to bring them back. So accurate result may not be obtained from measurements taken from cadavers. So in this study, we measured the length of a long bone (e.g. radius) to estimate the stature to get accurate result. Both upper and lower ends of the radius are subcutaneous, easily palpable, so its length can be easily measured. Very few works have been done in this regard especially in ethnic Bengali population. Keeping all these facts in mind, we tried to find out a valid formula to estimate stature of Bengali women from percutaneous length of radius using mathematical method.

\section{METHODS}

Cases most of the participants were selected as patients in OPD of different departments of Institute of Post Graduate Medical Education and Research, Kolkata, a tertiary care teaching hospital. Some were selected as volunteers from this college faculties, undergraduate \& postgraduate students and also from nonteaching staffs. Total 540 subjects were chosen. It is subdivided into a model group of 510 subjects and a test group of 30 subjects selected by simple random sampling (Using a computer-generated random number list) from the 540 subjects. The aim is to develop a predictive regression equation to estimate stature from radius length in the subjects belonging to model group. The 30 subjects served as the test group to compare their actual stature with the estimated stature for determination of validity of the regression equation.

\section{Inclusion Criteria}

1. Women aged between 21-50 years.

2. Their mother tongue was Bengali.

3. They were the permanent residents of West Bengal.

\section{Exclusion Criteria}

1. Visible deformity of spine or limbs.

2. History limb bone fracture.

3. Long term corticosteroid use.

4. Bone disorders during childhood or adolescence.

Stature was measured as the distance from crown to heel in standing erect posture with a calibrated anthropometer. The person's feet are opposed and bare, the trunk is stretched straight so that whole back touches the anthropometer. Eyes are straight forward so that lower margin of orbit lies in the same horizontal plane with upper margin of external auditory meatus (Frankfort's plane).11 Length of the radius was measured as follows: at first head of radius is palpated in the extended elbow, into the dimple lateral to olecranon process of humerus and by moving the forearm as pronation and supination. ${ }^{12}$ Radial styloid process was identified by palpation at the lateral aspect of the wrist joint in supinated forearm, by tracing along the lower lateral border of radius. ${ }^{12}$ The radial length was measured as the distance between most prominent and palpable part of radial head to its styloid process in supinated forearm by spreading calipers. ${ }^{13}$ Length of left and right radius was taken separately. All measurements were taken between 11 am to $3 \mathrm{pm}$ to eliminate diurnal variation if any. Each measurement was taken by the three observers separately in centimeter and an average of these three readings was taken.

\section{Statistical Analysis}

Data was summarized as descriptive statistics, namely mean, standard deviation (SD) and 95\% confidence interval (CI) of the mean. Paired numerical variables were compared between different groups by Student's ' $t$ ' test. ${ }^{14}$ Scattered plots were drawn to depict association between stature and length of the bone, and the strength of association expressed by Pearson's ${ }^{6}$ correlation coefficient (r). Multiple linear regression analysis was done using left and right radius and age as the predictor. The standard error of estimate (SEE) of the regression equation was calculated as the standard deviation of the residuals. The female gender specific regression equation was then applied to predict stature of the individual in the test group. The predicted stature and the actual measured stature were compared for agreement by calculating the interclass correlation coefficient (ICC) and drawing a Bland-Altman plot $^{15}$. $p<0.05$ was considered significant. Statistica Version 6 (Tulsa, Oklahoma: Stat Soft Inc. 2001) and MedCal Software Version 11.6 (Mariakerke, Belgium: MedCal Software, 2011) were used for statistical analysis.

\section{RESULTS}

Total sample was 540 subjects, 30 of these subjects were separated as the test cohort by simple random sampling. Rest 
510 comprised the model cohort. The data from this model cohort of 510 subjects is summarized in Table 1 . The mean length of left and right radius did not show statistical significance $(p=0.587)$

\begin{tabular}{|c|c|c|c|}
\hline Parameters & Range & Mean \pm SD & $\begin{array}{c}95 \% \text { Confidence Interval } \\
\text { of Mean }\end{array}$ \\
\hline Age (years) & $21-50$ & $35.2 \pm 8.52$ & $34.4-35.9$ \\
\hline Height $(\mathrm{cm})$ & $139-171$ & $153.8 \pm 6.79$ & $153.2-154.3$ \\
\hline Left radius length $(\mathrm{cm})$ & $18.8-29.9$ & $23.7 \pm 1.39$ & $23.5-23.8$ \\
\hline Right radius length $(\mathrm{cm})$ & $19.0-28.0$ & $23.7 \pm 1.36$ & $23.6-23.8$ \\
\hline \multicolumn{4}{|c|}{ Table 1. Descriptive Statistics of Variables $(n=510)$} \\
\hline
\end{tabular}

\begin{tabular}{|c|c|c|c|c|}
\hline $\begin{array}{l}\text { Independent } \\
\text { Variables }\end{array}$ & $\begin{array}{l}\text { Regression } \\
\text { Coefficient }\end{array}$ & $\begin{array}{l}\text { Standard } \\
\text { Error }\end{array}$ & $\mathbf{t}$ & $\mathbf{p}$ \\
\hline (Constant) & 39.2558 & & & \\
\hline Age & -0.003692 & 0.008625 & $\begin{array}{l}-0.428 \\
\end{array}$ & 0.6688 \\
\hline Left radius length & 0.3671 & 0.2166 & 1.695 & 0.0907 \\
\hline Right radius length & 4.4588 & 0.2208 & 20.190 & $<0.0001$ \\
\hline \multicolumn{5}{|c|}{$\begin{array}{l}\text { Table 2. Parameters of Multiple Regression Model Used to Develop a } \\
\text { Predictive Equation for Stature Based on Age and Radius Length } \\
\qquad(n=510)\end{array}$} \\
\hline \multicolumn{5}{|c|}{$\begin{array}{l}\text { Coefficient of determination }\left(\mathrm{R}^{2}\right) \text { for this model was } 0.94 \text { and Standard error of } \\
\text { estimate (Standard Deviation of the Residuals) was } 1.65 \mathrm{~cm} \text {. }\end{array}$} \\
\hline
\end{tabular}

Scatter plots were drawn to study the association between height in Y-axis and length of left or right radius in X-axis in the model cohort (Figure 1 and 2). The figures showed that association was clearly linear. So, simple linear regression equation and Pearson's correlation coefficient (r) were estimated for individual scatter plot. The correlation coefficients were statistically significant $(p<0.001)$. In Figure 1 , the equation of the regression line for left radius is $\mathrm{Y}=$ $44.495+4.6084 * \mathrm{X}(\mathrm{Y}=$ Height, $\mathrm{X}=$ left radius length $)$ and the $r$ value is 0.945 (95\% CI 0.935 to 0.965$)$ with $p<0.001$. The $\mathrm{SEE}$ is $1.65 \mathrm{~cm}$. In Figure 2, the equation of the regression line for right radius is $\mathrm{Y}=39.190+4.8225 * \mathrm{X}(\mathrm{Y}=$ Height, $\mathrm{X}=$ right radius length) and $r$ value is 0.969 (95\% CI 0.954 to 0.971 ) with $\mathrm{p}<0.001$. The SEE is $1.65 \mathrm{~cm}$.

The model cohort was further divided into three subgroups according to age: 21 - 30 years, $31-40$ years and 41 - 50 years ( $\mathrm{n}=170$ each). This showed no statistically significant difference between these subgroups. Subgroupswise scatter plots were also constructed (not shown) and the $r$ values calculated. These showed values similar to that of whole cohort. Multiple linear regression was used to develop a predictive equation to estimate stature based on age and left \& right radius lengths. These parameters are shown in Table 2. The coefficient of determination $\left(\mathrm{R}^{2}\right)$ was 0.94 . This means that nearly $95 \%$ of the variability in stature was explained by the three selected predictors. The SEE was $1.65 \mathrm{~cm}$. The final regression equation for stature estimation of Bengali women is:

\section{$H=39.2558+0.3671 \times L R+4.4588 \times R R-0.003692 \times$ age \pm 1.6546}

Where $\mathrm{H}=$ height of the person in $\mathrm{cm}, \mathrm{LR}=$ left radius length in $\mathrm{cm}, \mathrm{RR}=$ right radius length in $\mathrm{cm}$, age in years.

This equation was applied to predict the stature of the test cohort of 30 subjects. The extent of agreement between the actual stature and the estimated stature is depicted graphically by a Bland-Altman plot. The ICC value was 0.978 (95\% CI 0.963 - 0.987) indicating strong agreement.

\section{DISCUSSION}

Several investigators ${ }^{16,17,18}$ obtained the regression equations to calculate stature from length of limb bones. The equations are different from each other. This may be due to different racial population in the world.18,19,20,21 Many Indian studies are also there. Athawale 22 tried to estimate stature from the length of long bones of forearm in Maharastrian people and made a regression formula (irrespective of gender): Stature $=59.2923$ $\mathrm{cm}+4.1442 \mathrm{x}$ average length of right and left radius in $\mathrm{cm} \pm$ 3.66. He found an error of 5-8\% when compared with that of Western formula. Sarojini Devi et $\mathrm{al}^{23}$ calculated correlation coefficient as $r=0.619$ for male and 0.584 for females and made the regression equation to estimate stature from length of upper arm among living population of Maring tribes of Pullel area, Chandel district, Manipur.

In our study we took 510 women between the age group 21 and 50 years in Kolkata and nearby areas of West Bengal. Generally, ossification of radius is completed within 20 years of age. ${ }^{24}$ Beyond the age of 50 years there is possibility of osteoporosis or other degenerative bone diseases influencing the stature. ${ }^{25}$ So we took the age group of 21 to 50 years. The mean height was $153.8 \mathrm{~cm}$ (range $139-171 \mathrm{~cm}$ ). These values correlate well with the work of Basu ${ }^{26}$. He conducted a study on anthropometry in Bengali population in 1963.

In our study, the scatter plot shows positive linear relationship between stature and length of left and right radius. Here correlation coefficient exceeds 0.94 for both left and right radius. The $\mathrm{p}$ value was $<0.001$ which indicates that the association observed in the sample population might also be there in the whole population. Thus, length of radius is quiet acceptable for estimation of stature. Some research workers $5,27,28$ told that regression formulas using combination of multiple bones length is more accurate than using a single bone. Keeping all these things in mind, in this study we have taken age, left and right radius lengths as parameters to produce a predictive equation. The quality of the regression equation is assessed on the basis of its standard error of estimate (SEE). Here SEE is $1.65 \mathrm{~cm}$ which is quite low as compared to the values of Trotter and $\operatorname{Gleser}^{7}(4.24-5.05 \mathrm{~cm})$, of Athawale $22(3.66 \mathrm{~cm})$, of Dayal et $\mathrm{al}^{28}(3.58 \mathrm{~cm})$ and of Mahakkanukrauh et $\mathrm{al}^{29}(5.63 \mathrm{~cm})$. The low value of SEE in our study is highly indicative of acceptance of the regression equation.

\section{CONCLUSIONS}

When the predictive equation is applied in the test cohort of 30 randomly selected women to find out their stature, it shows a strong agreement with the directly measured stature. So, a conclusion can be drawn that this equation can be used to calculate the stature of Bengali women population from their left \& right radius lengths. 


\section{REFERENCES}

[1] Galton F. Regression towards mediocrity in heriditary stature. Journal of the Anthropological Institute of Great Britan and Ireland 1886;15:246-63.

[2] Marshall WA, Tanner JM. Growth and physiological development during adolescence. Annu Rev Med 1968;19:283-300.

[3] Lundy JK. The mathematical versus anatomical methods of stature estimation from long bones. Am J Forensic Med \& Pathol 1985;6(1):73-6.

[4] Fully G. New method of determination of the height. Ann Med Leg Criminol Police Sci Toxicol 1956;36(5):266-73.

[5] Lundy JK. Regression equation for estimating living stature from the long limb bones in South African Negroes. S Afr J Sci 1983;79:337-8.

[6] Pearson K. Mathematical contributions to the theory of evolution: on the reconstruction of the stature of prehistoric races. Phil Trans Roy. Soc Lond A 1899;192:169-244.

[7] Trotter M, Gleser GC. A re-evaluation of estimation of stature based on measurement of stature taken during life and of long bones after death. Am J Phys Anthropol 1958;16(1):79-123.

[8] Ozaslan A, Koc S, Ozaslan I, et al. Estimation of stature from upper extremity. Military Medicine 2006;171(4):288-91.

[9] Bidmos M, Asala S. Calcaneal measurement in estimation of stature of South African blacks. Am J Phys Anthropol 2005;126(3):335-42.

[10] Celbis O, Agritmis H. Estimation of stature and determination of sex from radial and ulnar bone lengths in a Turkish corpse sample. Forensic Sci Int 2006;158(23):135-9.

[11] Garson JG. The Frankfort Craniometric agreement, with Critical Remarks thereon. J Anthrop Inst 1884;14:64-83.

[12] Datta AK. Essential of human anatomy. Superior and inferior extremities. $4^{\text {th }}$ edn. Kolkata: Current Book International 2009: p. 14, 261.

[13] Spreading Caliper: manufacturer is ICS (Industrial \& Commercial Services), Nacharam, Hyderabad, Telangana, 2019.

[14] Student's ' $t$ ' test was introduced in by William Sealy Gosset, a chemist in Dublin, Ireland. 'Student' was his pen name. ' $t$ ' stands for two sets of data. 1908.
[15] Bland JM, Altman DG. Measuring agreement in method comparison studies. Statistical Method in Medical Research 1999;8(2):135-60.

[16] Telkka A. On the prediction of human stature from the long bones. Acta Anat (Basel) 1950;9(1-2):103-17.

[17] Dupertuis CW, Hadden JA Jr. On the reconstruction of stature from long bones. Am J Phys Anthropol 1951;9(1):15-54.

[18] Trotter M, Gleser GC. Estimation of stature from long bones of American Whites and Negroes. Am J Phys Anthropol 1952;10(4):463-514.

[19] Keen EN. Estimation of stature from long bones: a discussion of its reliability. J Forensic Med 1953;1:46-51.

[20] Genoves S. Proportionality of the long bones and their relation to stature among Meso-Americans. Am J Phys Anthropol 1967;26(1):67-77.

[21] Lundy JK, Feldesman MR. Revised equation for estimating living stature from long bones of the South African Negroes. S Afr J Sci 1987;83:54-5.

[22] Athawale MC. Estimation of height from length of forearm bones: a study of one hundred Maharastrian male adults of age between twenty-five and thirty years. Am J Phys Anthropol 1963;21(2):105-12.

[23] Devi S, Das H, Purnabati BK, et al. Estimation of stature from upper arm length among the Marings of Manipur. Ind Med J 2006;100(8):271-3.

[24] Krishna G. BD Chaurisia's Human Anatomy. Upper limb \& thorax. Vol. 1. $8^{\text {th }}$ edn. CBS Publisher 2016: p. 21.

[25] Longo D, Fauci A, Kasper D, et al. Harrison's Principles of Internal Medicine. 18 ${ }^{\text {th }}$ edn. McGraw-Hill Publisher 2012: p. 2833,3120 .

[26] Basu A. Anthropometry of the Kayasthas of Bengal. J Anat Soc India 1963;3:20-5.

[27] Choi BY, Chae YM, Chang IH, et al. Correlation between the postmortem stature and the dried limb-bone lengths of Korean adult males. Yonsei Med J 1997;38(2):79-85.

[28] Dayal MR, Steyn M, Kuykendall KL. Stature estimation from bones of South African Whites. S Afr J Sci 2008;104(3-4):124-8.

[29] Mahakkanukrauh P, Khanpetch P, Prasitwattanseree S, et al. Stature estimation from long bone lengths in a Thai population. Forensic Sci Int 2011;210(1-3):279, e1-7. 